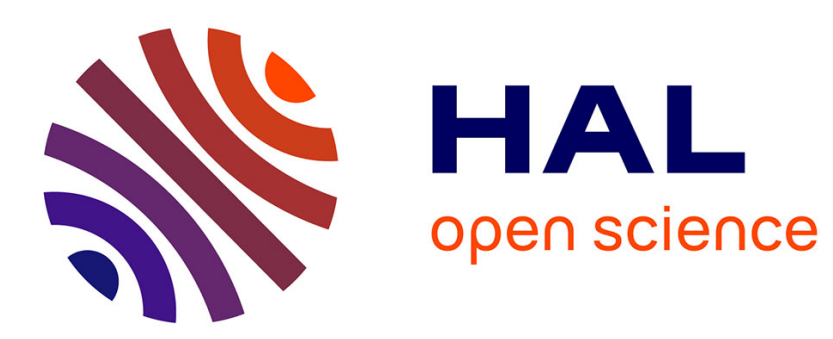

\title{
Thermomechanical process intensification for oil extraction from orange peels.
}

Sid-Ahmed Rezzoug, Nicolas Louka

\section{To cite this version:}

Sid-Ahmed Rezzoug, Nicolas Louka. Thermomechanical process intensification for oil extraction from orange peels.. Innovative Food Science \& Emerging Technologies / Innovative Food Science and Emerging Technologies , 2009, 10 (4), pp.530-536. 10.1016/j.ifset.2009-2005.008 . hal-00414230

\section{HAL Id: hal-00414230 \\ https://hal.science/hal-00414230}

Submitted on 8 Sep 2009

HAL is a multi-disciplinary open access archive for the deposit and dissemination of scientific research documents, whether they are published or not. The documents may come from teaching and research institutions in France or abroad, or from public or private research centers.
L'archive ouverte pluridisciplinaire HAL, est destinée au dépôt et à la diffusion de documents scientifiques de niveau recherche, publiés ou non, émanant des établissements d'enseignement et de recherche français ou étrangers, des laboratoires publics ou privés. 
1*Laboratoire d'Etude des Phénomènes de Transferts et de l'Instantanéité, Agro-Industrie et Bâtiment, LEPTIAB (EA 4226), Pôle Sciences et Technologies, Avenue Michel Crépeau, Université de La Rochelle, 17042 La Rochelle, France

${ }^{2}$ Université Saint Joseph - Faculté des sciences. Campus des sciences et technologies. Mar Roukos - Mkallès. B.P. 11-514 - Riad El Solh. Beyrouth 1107 2050, Liban 


\section{Abstract}

\section{(}

The study investigated the intensification and improvement of oil extraction from orange peel through a thermomechanical process: the Instantaneous Controlled Pressure Drop (briefly D.I.C process). This process involves subjecting orange peel for a short time to steam pressure, followed by an instantaneous decompression to vacuum at 50 mbar. Central composite design was used to study the combined effects of processing steam pressure $(1-7$ bar; which corresponds to a temperature ranging between $100^{\circ} \mathrm{C}$ and $162{ }^{\circ} \mathrm{C}$ respectively), processing time (0.3 - 3.7 min.) and initial moisture content of orange peel before thermomechanical oil extraction $(9.8-60.2 \%$ on dry material basis). The quantitative analysis, have been undertaken on oil present in orange peels, after processing. Correlation analysis of the mathematical regression model indicated that quadratic polynomial model could be employed to optimize the extraction of oil from orange peel. From response surface plots, the three variables exhibited a linear effect with the strongest effect for the processing pressure. The optimum reaction conditions selected with response surface analysis were as follows: steam processing pressure: 6.6 bar, processing time: $3.68 \mathrm{~min}$, initial moisture content: $53.6 \%$ d.m basis. Under these conditions, experimental yield of orange peel oil was close to predicted value (99\%) calculated from the polynomial response surface model equation. A kinetic study indicated that extraction performed by D.I.C process is clearly quicker than conventional steam distillation method.

2 Keywords : orange peel, extraction, oil, Controlled Instantaneous Pressure Drop (D.I.C extraction process), response surface methodology. 
World production of citrus fruit has experienced continuous growth in the last decades of the XX century. Total annual citrus production was estimated at over 105 million tons in the period 2000-2004 (http://www.unctad.org/infocomm/anglais/orange/market.htm). Oranges constitute the bulk of citrus fruit production, accounting for more than half of global citrus production in 2004. Thus, the quantities of generated by-products are very important. In this study, extraction of oil from orange peel was performed through a termomechanical process developed in our laboratory (Rezzoug, Boutekedjiret \& Allaf, 2005). We report on some results obtained using this process as well as others comparing extraction kinetics when using a conventional steam distillation process and the proposed extraction process. One of advantages of the described method is the short contact of extracted oil with the heated zones in the apparatus resulting in a lower heating of the product compared to steam distillation. At industrial scale, this is interesting regarding oil quality and energy saving.

\section{1- Introduction}

Peel of citrus fruits is one of the by-products of fruit processing which provides a great potential for further commercial use. The various species of citrus elaborate and stock essential oils in schizolysigen pockets localized in the external part of the mesocarpe of fruit (flavedo). These oils are used as flavouring ingredients in a variety of foods such as soft drinks or ice cream as well as in formulation of several products in parapharmacy and perfume industry (Raeissi, Diaz, Espinosa, Peters \& Brignole, 2008). Another application makes use of germicidal properties of some of their components. Redd and Hendrix (1993) reported that a small amount of the dlimonene was very effective in the germicide treatment of waste water. It is well known that 
activities (Ur-Rehman, 2006; Pernice, Boriello, Ferracane, Borrelli \& Cennamo, 2009; ViudaMatros, Ruiz-Navajas, Fernández-López \& Pérez-Álvarez, 2008). Few studies have been conducted on extraction of citrus essential oils in general and oil from orange peel in particular (Ferhat, Meklati, Smadja \& Chemat, 2006; Berna, Tárrega, Blasco \& Subirats, 2000), although studies on the deterpenation or separation of the different hydrocarbons composing citrus oils are more abundant (Diaz, Espinosa \& Brignole, 2005; Danielski, Brunner, Schwänke, Zetzl, Hense \& Donoso, 2008; Arce, Pobudkowska, Rordíguez \& Soto, 2007; Dugo, Mondello, Bartle, Clifford, Breen \& Dugo, 1995; Raeissi and Peters, 2005)

Supercritical fluids extraction processes have gained an increasing importance in chemical and food industry since they can maximize product recovery and improve product quality (Budich, Ullrich, Jung \& Brunner, 1997; Grosso, Ferraro, Figueiredo, Barroso, Coelho \& Palavra, 2008; Yu, Dandekar, Toledo, Singh \& Patil, 2007). The interest of this method lies in criteria which are not fulfilled by classical extraction methods such as the solvent inertness and toxicity. In fact, fractionation can be done at moderate temperatures and without remaining organic solvent (Temelli, Chen \& Braddock, 1988). This is important for terpenes which tend to decompose at high temperatures. However, technological conditions for using supercritical fluid extraction at industrial scale are restrictive and the high production costs of specific products have limited the use of this process. For these reasons, several authors tried to improve the classical methods of citrus oil extraction. Tateo (1990) developed a "thin film evaporator system" which has as advantage to work under mild temperature conditions. Fleisher (1990), through a process called "Poroplast" has tempted to minimize the quantity of solvent used in essential oil extraction of different citrus products. In the last decade, there has been an increasing demand for new extraction techniques enabling automation, shortening of extraction time and reducing of organic solvent consumption with a special attention to energy prices and reduction of $\mathrm{CO}_{2}$ emissions. 
81 Many researchers as Bousbsia, Vian, Ferhat, Meklati and Chemat (2008) or others cited by these authors focused their works on novel techniques and sustainable extraction processes.

The aim of this work was to provide an efficient and economically attractive process for extraction of essential oil from orange peel through a thermomechanical extraction technique developed in our laboratory: the Instantaneous Controlled Pressure Drop process. This process known as "D.I.C", was developed and patented in our laboratory some years ago (Rezzoug, Baghdadi, Louka, Boutekedjiret \& Allaf, 1998; Allaf et al, 1999) initially for using in the field of drying-texturation of various food products by improving hydration capacity (Rezzoug, Louka, Maache-Rezzoug, Nouviaire \& Allaf, 1998; Rezzoug, Maache-Rezzoug, Mazoyer, Jeannin and Allaf, 2000). This process is based on a thermo-mechanical processing induced by subjecting the product to a fast transition from high steam pressure to vacuum. For food products such as vegetables, the aim was to improve the vaporization of water with a preservation of fragrance coupled to an alveolate texture of dried product, while in the present study this process was used for the separation of volatile oil from the solid material. This extraction process, successfully tested on isolation of essential oil from rosemary leaves (Rezzoug et al., 1998) represents an interesting alternative not only to classical processes such as extraction by solvent and steam distillation, but also to more effective processes such as extraction with supercritical fluids. In fact, this extraction process does not require using of any solvent and induced cooling when the plant is rapidly transferred from a high steam pressure to vacuum stops all thermal degradation of oil components. Due to the "flash" evaporation of bulk water present in peels, the processing

101 by instantaneous controlled pressure drop increases the global diffusivity of the product and 102 improves availability of the liquid in plant. Moreover, compared to steam distillation, the short 103 time contact (few minutes) between plant and heat avoids the loss and degradation of volatile and thermolabile compounds. 
105 The response surface methodology (RSM) has been successfully applied for optimizing

106 conditions in food research (Wu, Cui, Tang \& Gu, 2007, Ghodke, Ananthanarayan \&Rodrigues,

107 2009; Wang, Yang, Du, Yang \& Liu, 2008) but few studies focused on optimization of

108 extraction of oils from various plants (Sonsuzer, Sahin \& Yilmaz, 2004; Zeboudj, Belhanèche-

109 Bensemra \& Belabbès, 2005). RSM is defined as a statistical method using quantitative data

110 from an appropriate experimental design to determine and simultaneously solve multivariate

111 equations. The main advantage of RSM is the reduced number of experimental trials needed to

112 evaluate multiple parameters and their interactions. This paper aims to assess the effect of the

113 main processing parameters of D.I.C extraction process, namely the processing steam pressure,

114 processing time and initial moisture content of the peels, on extraction efficiency of oil from

115 orange peel (Citrus sinensis) and to determine the optimum conditions using RSM analysis.

\section{2- Experimental procedures}

\section{$117 \quad$ 2.1- Plant material}

118 Oranges used in this study were citrus sinensis L., grown in Valencia (Spain). The peels were 119 separated from the endocarp by cutting with hand knife and cut into 6-8 pieces giving yield of 17

$120 \%(\mathrm{w} / \mathrm{w})$ of orange peels with respect to whole fruit. The peels were used without milling and

121 were softly dried at $40{ }^{\circ} \mathrm{C}$ in a drying oven by a flow air and then placed in hermetically sealed

122 bags and stored in a cold chamber until treatment. The moisture content of dehydrated orange

123 peels, measured by Mettler LP16 infrared balance was $0.0685 \mathrm{~kg} \mathrm{H}_{2} \mathrm{O} \mathrm{kg}^{-1} \mathrm{dm}$. The yield of oil

124 in raw material, as described in section 2.3.c, was $2.06 \%$ by mass (dry basis). This value is in 125 agreement with data previously obtained by Salib, Saleh \& Abdel-Malik (1978) for Egyptian 126 orange peel oil and by Dugo, Mondello, Bartle, Clifford, Breen \& Dugo (1995) for extraction by 127 supercritical $\mathrm{CO}_{2}$ processing of Sicilian orange peel oil.

\section{2- Instantaneous controlled pressure drop apparatus}


129 Figure 1 gives a representative diagram of used equipment and the pressure profile is presented

130 in figure 2. Humidified orange peel is firstly placed in the processing vessel (fig.1.2) at

131 atmospheric pressure before vacuum setting ( 50 mbar) (fig.2a and $2 \mathrm{~b}$ ). Vacuum build-up is

132 obtained by communication with the vacuum tank (fig.1.4 and fig.2b). This initial vacuum

133 facilitates the diffusion of steam into product and allows its rapid heating. After closing the valve

134 (fig 1.3), an atmosphere of saturated steam under pressure is introduced in processing vessel

135 (fig.2c). The thermal processing is followed by a rapid decompression (fig.2e) insured by a

136 communication (in less than 1/10 second) between processing vessel and vacuum container

137 (fig.1.4) which has a volume (250 litres) 80 times that of processing vessel (3.2 litres). Initial

138 vacuum level in the processing vessel was maintained at 50 mbar during all experiments. This

139 transition induces a rapid modification of the thermodynamic equilibrium reached during the

140 pressurisation $\left(\mathrm{P}_{1}, \mathrm{~T}_{1}\right)$ towards another equilibrium state $\left(\mathrm{P}_{2}, \mathrm{~T}_{2}\right)$. Equilibrium pressure after

141 decompression depends on the level of processing pressure: the higher the processing pressure,

142 the higher the equilibrium pressure. In our case, it varied from 62 up to 120 mbar when

143 processing pressure increases from 1 to 7 bar. The followed vaporization, as an adiabatic

144 transformation, induces a rapid cooling of the residual product. After the vacuum phase,

145 atmospheric air is injected to return to atmospheric pressure for sample recovery (fig. $2 \mathrm{f}$ ).

\section{2.3- Procedures adopted for the characterization of isolated orange peel oil}

$147 \quad$ a- Isolation of essential oil

148 Figure 3 depicts the procedure of extracted oil characterisation. Each experiment begins with

149 humidification of the orange peel at fixed initial moisture content, followed by 12 hours

150 conservation stage in refrigerated atmosphere $\left(4 \sim 5{ }^{\circ} \mathrm{C}\right)$ in order to homogenize moisture in

151 whole product. The feed reactor with typically $100 \mathrm{~g}$ of humidified peels undergoes a thermo-

152 mechanical treatment, at fixed processing pressure and processing time. After the rapid 
153 decompression, orange peels are recovered and analyzed. In order to quantify the essential oil

154 remaining in orange peels, a classical extraction procedure of steam distillation was used. Two

155 distinct phases were obtained, an organic phase (isolated oil) and an aqueous phase containing a

156 small part of oil. The organic phase was separated from the aqueous phase with $10 \mathrm{ml}$ of hexane

157 and then analyzed by gas chromatography. Procedures of steam distillation and gas

158 chromatography are described hereafter.

159 b-Gas chromatography $(G C)$

160 GC analysis was performed using a Shimadzu-GC-14A gas chromatograph. GC conditions were

161 as follows: fused silica column $(12 \mathrm{~m} * 0.32 \mathrm{~mm}$ i,d., film thickness $0,25 \mathrm{~mm}$, liquid stationary

162 phase: silicone, detection by FID, split ratio $100: 1$ ). Oven temperature $50{ }^{\circ} \mathrm{C}$ for 1 minute then

163 programmed from 50 to $250{ }^{\circ} \mathrm{C}$ at $5{ }^{\circ} \mathrm{C} / \mathrm{min}$, and 2 minutes at $250{ }^{\circ} \mathrm{C}$. Injection temperature 200

$164{ }^{\circ} \mathrm{C}$, detection temperature $280{ }^{\circ} \mathrm{C}$. Carrier gas nitrogen $(1 \mathrm{ml} / \mathrm{min})$. Volume of injection $0,5 \mathrm{ml}$.

165 Gas chromatograph was connected with a Merck D-2500 chromato-integrator. Identification of

166 volatile compounds was based on a comparison with injection of references compounds

167 (provided by Aldrich-Chimie, France).

169 Classical S.D method of extraction was used with $50 \mathrm{~g}$ of orange peel treated by D.I.C process 170 and $350 \mathrm{ml}$ of water. The duration of extraction by steam distillation was 2 hours. As extraction 171 solvent, $10 \mathrm{ml}$ of distilled hexane was used. Identified compounds and their yield are grouped in 172 table 1 . The yields of identified compounds are close to those reported by Lawrance (1990) about 173 Portuguese and Argentinean orange peel oil, by Buldish, Ullrich, Jung \& Brunner (1997), and by

174 Mira, Blasco \& Subirats (1996) for orange peel oil obtained by supercritical fluid extraction. 
175 From table 1, it is clear that orange peel oil obtained by S.D is composed in large part of

176 limonene. As monoterpenes, we also identified, $\alpha$-pinene, $\beta$-pinene, and myrcene and as

177 oxygenated compounds, linalool have been identified.

178 The maximum oil extraction yield obtained by SD was about $2.06 \mathrm{~g}$ based on $100 \mathrm{~g}$ of dried feed 179 material (see section 3.3). The oil yield was determined according to the quantity of oil remained 180 in orange peel:

$$
\text { oil yield }(\%)=\left(\frac{2.06-\text { extract in treated peels }}{2.06}\right) \times 100
$$

\section{4- Experimental design}

183 A response surface methodology was employed for optimizing the operating conditions of the

D.I.C process to give high yield of liquid extract i.e. to minimize the quantity of essential oil which remains in orange peels. This quantity is assumed to be affected by three independent variables, $\xi_{\mathrm{i}}$ (processing pressure $\xi_{1}$, initial moisture content of orange peel $\xi_{2}$ and processing time $\xi_{3}$ ). It is also assumed that the response $\eta$ (oil yield), which was experimentally measured,

188 defined the system.

$$
\eta=f\left(\xi_{1}, \xi_{2}, \xi_{3}\right)
$$

190 Second degree polynomial equation were assumed to approximate the true function :

$$
\eta=\beta_{0}+\sum_{\mathrm{i}=1}^{3} \beta_{i} x_{i}+\sum_{\mathrm{i}=1}^{3} \beta_{\mathrm{ii}} \mathrm{x}_{\mathrm{i}}{ }^{2}+\sum_{\mathrm{i}=1}^{2} \sum_{\mathrm{j}=\mathrm{i}+1}^{3} \beta_{\mathrm{ij}} \mathrm{x}_{\mathrm{i}} \mathrm{x}_{\mathrm{j}}
$$

192 where $\beta_{0}, \beta_{i}, \beta_{i i}$ and $\beta_{i j}$ are regression coefficients, and $x_{i}$ are the coded variables linearly related

193 to $\xi_{\mathrm{i}}$. The coding of $\xi_{\mathrm{i}}$ into $x_{i}$ is expressed by the following equation:

$$
x_{i}=\frac{2\left(\xi_{i}-\xi_{i}^{*}\right)}{d_{i}}
$$


195 where $\xi_{\mathrm{i}}=$ actual value in original units; $\xi_{\mathrm{i}}{ }^{*}=$ mean of high and low levels of $\xi_{\mathrm{i}}$; and $d_{i}=$

196 difference between the low and high levels of $\xi_{\mathrm{i}}$.

197 A central composite rotatable design (Benoist, Tourbier \& Germain-Tourbier, 1994) was used.

198 For the three variables, the design yielded 22 experiments with eight $\left(2^{3}\right)$ factorial points, six 199 axial points to form a central composite design and eight center points for replications. The range 200 and the centre point were chosen after preliminary trials (Table 2). The 22 experiments were run 201 in random order to minimize the effects of unexpected variability in observed responses due to 202 extraneous factors. Response surfaces as represented by Fig. 4 were drawn by using the analysis 203 design procedure of Statgraphics Plus for Windows software (5.1 version).

\section{3- RESULTS AND DISCUSSION}

\section{1- Model fitting}

In order to develop response surface equation for predicting the percentage of extracted oil in the range of conducted study, the experimentally determined oil yield percentages were fitted to Eq.1. The responses generated from experiments are presented in table 3 along with the 209 predicted yield values. A good fit was obtained between experimental and predicted data. It can 210 be seen that for the lower processing time $(\sim 18 \mathrm{sec})$ the yield was already about $37 \%$ (run 13 ).

211 The regression coefficients of equation describing the responses surfaces are grouped in Table 4 212 which shows that $x_{1}$ (processing pressure) linearly and quadratically affected the oil yield (p213 value $<0.01$ ). However, $x_{3}$ (processing time), and in a lesser extent $x_{2}$ (initial moisture content) 214 affected only linearly the response ( $\mathrm{p}$-value<0.06). There were no significant two-factor 215 interactions. It should be noted that p-value indicates the statistical significance of each 216 parameter. It is based on hypothesis that a parameter is not significant, thus the more this 217 probability is close to zero, the more effect is significant.. 
218 According to table 4, the yield $\eta$ is given by Eq.5:

$\eta=\beta_{0}+\beta_{1} x_{1}+\beta_{2} x_{2}+\beta_{3} x_{3}+\beta_{11} x_{1}^{2}+\beta_{22} x_{2}^{2}+\beta_{33} x_{3}^{2}+\beta_{12} x_{1} x_{2}+\beta_{13} x_{1} x_{3}+\beta_{23} x_{2} x_{3}$,

220 where $x_{1}, x_{2}$ and $x_{3}$ are the coded values for processing pressure, moisture content of peels and 221 processing time respectively.

222 A summary of variance analysis (ANOVA) is given in table 5. The Fisher's test (F-test) carried out on experimental data make it possible to estimate the statistical significance of the proposed model. The F-test value of the model being 6.53 with a low probability value $(\mathrm{p}<0.01)$, we can conclude that it is statistically significant at $99.9 \%$ confidence level. As indicated by the coefficient of determination $\mathrm{R}^{2}$ in table 5 , the predicted model seemed to reasonably fit to experimental values, since the fitted model could explain $89 \%$ of total variation.

3.2- Effects of processing pressure, processing time and initial moisture content on oil extraction yield

Table 4 indicates that the linear terms related to processing pressure and to processing time were statistically significant as proven by the low p-value $(<0.0001$ and 0.0024 respectively $)$. This is also obvious when considering Fig. 4, which shows the tri-dimensional response surface for the yield in extracted oil. Both processing time and processing pressure demonstrated a linear increase on extraction yield, with the strongest effect for the processing pressure which imposes the $\Delta \mathrm{P}$ of the pressure drop. In a recent work, this thermomechanical process, used in isolation of extractives from red cedar wood (Mellouk, Khezami, Rezzoug \& Capart, 2008), also showed a strong linear effect of processing pressure.

238 From fig.4a, it can be seen that for a processing time and initial moisture content of orange peel 239 fixed at their central values ( $2 \mathrm{~min}$. and $35 \%$ respectively), extraction yield increased from 49.4 $240 \%$ to $73.9 \%$ when processing pressure increased from 2.2 to 5.8 bar. On the other hand, when 
the processing pressure and initial moisture content of orange peel were fixed at their central value (4 bar and $35 \%$ respectively), the change in the extraction rate was only from $48.4 \%$ to $60.4 \%$ when processing time increased from 1 to 3 minutes (fig $4 \mathrm{c}$ ). This is probably the result of two simultaneous effects: a free diffusion phenomenon on the peels surface and a mechanical strain resulting from the drop of steam pressure with a subsequent degradation of cells. This degradation therefore involves the liberation of compounds initially located in intact cells. Spiro and Chen (1994) reported that the essential oil synthesized in secretory cells is not released unless an external factor damages the microstructure. The same authors (Chen and Spiro 1995) reported that a severe thermal stress such as irradiation with high microwave power, and the build-up within the cells could have exceeded their capacity for expansion, thus causing their 251 breaking. This expansion phenomenon was also observed by Nouviaire et al, (2001) for fruits as apples treated with D.I.C process. Fig. 4b also shows that it is possible to obtain a high extraction yield oil for a low processing time $(\sim 1 \mathrm{~min})$ but at high processing pressures $(5 \mathrm{bar})$ indicating 254 that the mechanical strain induced by the rapid decompression and the brutal vaporization has as 255 effect a change in the surface tension of the glandular wall, causing it to crumble or rupture more 256 readily. Similar effects were pointed out by Pare, Sigomin \& Lapointe, (1991) for microwave 257 extraction. The authors reported that an explosion at cell level occurred as a consequence of the 258 sudden temperature rise generated by microwaves. In this work, increasing of steam pressure 259 leads also to a temperature rise. The collapse and rupture phenomenon's were also confirmed by 260 scanning electron micropgraphs on extraction of rosemary oil by instantaneous controlled 261 pressure drop process (Rezzoug et al, 1998). Concerning effect of initial moisture content of 262 peels, it can be seen that it displays an intermediate linear effect $(\mathrm{p}=0.0588)$. This linear effect 263 can be explained by the quantity of water in orange peel. The higher is this quantity, the higher is 
264 the evaporation, with intensive vapor formation and thus sweeping of orange peels oil compounds.

\section{3- Kinetics of oil extraction from orange peel}

A comparative kinetic study between extraction by steam distillation which is the reference method and by extraction with D.I.C process was performed. The maximum yield $(2.06 \mathrm{~g} / 100 \mathrm{~g}$ d.m) for the steam distillation method was obtained after 90 to 100 minutes processing. For extraction by D.I.C technique, we have studied the variation of yield versus processing time by keeping constant processing pressure ( 7 bar) and initial moisture content of peels $(35 \%$ d.m). As illustrated by figure 5, for 1 minute processing time, more than half of available oil was extracted and for 4 minutes, extracted oil was equivalent to that obtained after 100 minutes by steam distillation. In the two cases, oils have the same composition gathered in table 1 but for steam distillation, a degradation of isolated oil, expressed by a more deepened colouring was observed (Fig. 6). Oil extraction yield was assumed to obey to a first order kinetic law, an assumption supported by various authors such as Spiro and Selwood (1984). In integrated form, the kinetics are described by Eq. 6,

$$
\ln \left(\frac{\mathrm{y}_{\infty}}{\mathrm{y}_{\infty}-\mathrm{y}(\mathrm{t})}\right)=\mathrm{k}_{\mathrm{i}} \mathrm{t}+\mathrm{a}
$$

where $\mathrm{y}_{\infty}$ is the yield at end of process, $\mathrm{y}(\mathrm{t})$ extraction yield at " $\mathrm{t}$ " time, $\mathrm{k}_{\mathrm{i}}$ a first-order rate constant, and "a" the semi empirical intercept. For the two techniques, extraction of oil occurred in two distinct kinetic steps as testified by the rupture of slope in the linear plots drawn in figure 7. Each step was characterised by its own kinetic constant. It is clear from fig.7 (a) that the change in oil yield versus time was fast during the first 2 minutes of the D.I.C extraction process with a high kinetic constant $\left(\mathrm{k}_{1}=0.755 \mathrm{~min}^{-1}\right)$ and slower beyond this period before reaching an equilibrium value $\left(\mathrm{k}_{2}=0.095 \mathrm{~min}^{-1}\right)$. An inverse trend was observed for extraction by steam 
distillation for which the slowest period was observed at the beginning of extraction process. Figure 7 indicates that in the two periods, the kinetics constants were lower to those obtained for D.I.C extraction process. This is probably due, for the thermomechanical proposed process, to a combination of heat treatment provided by steam and mechanical effect provided by the sudden 292 pressure drop while for steam distillation only heat treatment is present.

293 The reduced cost of extraction is clearly advantageous for the proposed D.I.C method in terms of 294 time and energy saving. The energy required to perform the two extraction methods were respectively $0.13 \mathrm{kWh} / \mathrm{g}$ of isolated oil for steam distillation, and $0.014 \mathrm{kWh} / \mathrm{g}$ of isolated oil for D.I.C extraction process. The power consumption was determined according to the quantity of steam required and to vacuum pump energy consumption. Regarding the environmental impact, the calculated quantity of carbon dioxide rejected in atmosphere is largely higher for steam distillation (from 115.8 to $127,1 \mathrm{~g} \mathrm{CO}_{2} / \mathrm{g}$ of extracted oil) than for the proposed D.I.C extraction process (from 12.5 to $13.7 \mathrm{~g} \mathrm{CO}_{2} / \mathrm{g}$ of extracted oil), for 7 bar as processing pressure. These 301 calculations were preformed according to literature provided by the French Nuclear Energy 302 Society (http://www.sfen.org/fr/societe/developpement/edf.htm; downloaded on September 25, 303 2008): to obtain $1 \mathrm{kWh}$ from coal and fuel, respectively 978 and $891 \mathrm{~g}$ of $\mathrm{CO}_{2}$ is rejected in atmosphere during combustion.

\section{4- Conclusion}

This study clearly shown that oil yield from orange peel was more influenced by the processing

307 pressure than by processing time and initial moisture content of peels. However, the three 308 variables exerted a positive linear effect. The empirical model gave $\mathrm{R}^{2}$ of 0.89 and $\mathrm{P}$-value of 309 less than 0.01, which implied a good agreement between the predicted values and actual values of oil yield. The optimal conditions to obtain the highest yield are showed in fig.8: 6.6 bar for the 311 processing pressure; $53.6 \%$ for the initial moisture content of peels and 3.68 minutes for 
312 processing time. The kinetic study performed on the thermomechanical proposed process (D.I.C)

313 and conventional steam distillation process indicated that for both methods the extraction process

314 can be divided in two steps and that in the two cases the amount of oil recovered in the first step

315 was about $90 \%$ of available orange peel oil. However, the first step represents 2 minutes for the 316 proposed thermomechanical extraction process and 80 minutes for steam distillation process. 317 Thus, using this method, a reproducible extraction can be achieved in few minutes without 318 adding any solvent, representing economic and ecologic advantages. 


\section{REFERENCES}

Allaf, K. Maache-Rezzoug, Z. Louka, N. Debs-Louka, E. Abraham, G. Rezzoug, S.A., Habba, A (1998). French patent WO/1999/042003.

Arce, A., Pobudkowska, A., Rordíguez, O., Soto, A. (2007). Citrus essential oil terpenless by extraction using 1-ethyl-3-methylimidazolium ethylsulfate ionic liquid: Effect of the temperature. Chemical engineering journal, 133, 213-218.

Benoist, D., Tourbier Y., and Germain-Tourbier S. (1994). Plan d'expériences: construction et analyse". Lavoisier TEC \& DOC. Chapter 5, 208-389

Berna, A., Tárrega, Blasco, M., Subirats. (2000). Supercritical $\mathrm{CO}_{2}$ extraction of essential oil from orange peel; effect of the height of the bed. Journal of supercritical fluids, 18, 227 237.

Bousbsia, N., Vian, M.A., Ferhat, M.A., Meklati, B.Y., Chemat, F. (2008) A new process for extraction of essential oil from citrus peels: microwave hydrodiffusion and gravity. Journal of Food engineering. doi: 10.1016/j.foodeng.2008.06.034.

Buldish, M., Ullrich, J., Jung, S. and Brunner, G. (1997). Multistage Counter-Current Extraction of Orange Peel Oil Using Supercritical Carbon Dioxide. Proc. of First European Congress on Chemical Engineering, ECCE-1, Florence, Italy, May 4-7, 2703-2706

Chen, S. S., and Spiro, M. (1995). Kinetics of microwave extraction of rosemary leaves in hexane, ethanol and a hexane+ethanol mixture. Flavour and Fragrance Journal, 10, 101112.

Danielski, L., Brunner, G., Schwänke, C., Zetzl, C., Hense, H. and Donoso, J.P.M. (2008). Deterpenation of mandarin (Citrus reticulata) peel oils by means of countercurrent multistage extraction and adsorption/desorption with supercritical $\mathrm{CO}_{2}$. Journal of supercritical fluids, 44, 315-3240.

Diaz, S., Espinosa, S. and Brignole, E.A. (2005). Citrus oil deterpenation with supercritical fluids. Optimal process and solvent cycle design. Journal of supercritical fluids, 35, 49-61

Dugo, P., Mondello, L., Bartle K.D., Clifford, A.A., Breen, D.G.P.A. and Dugo, G. (1995). Deterpenation of sweet orange and lemon essential oils with supercritical carbon dioxide 
Ferhat, M.A., Meklati, B.Y., Smadja, J. and Chemat, F. (2006). An improved microwave Clevenger vapparatus for distillation of essential oils from orange peel. Journal of Chromatography A, 1112, 121-126

Fleisher, A. (1990). The Poroplast Extraction Technique in the Flavor and Fragrance Industry. Perfumer \& Flavorist, 15, 27-36

Ghodke, S.K., Ananthanarayan, L. and Rodrigues, L. (2009). Use of response surface methodology to investigate the effects of milling conditions on damaged starch, dough stickiness and chapatti quality. Food Chemistry, 112, 1010-1015.

Lawrence, B.M. (1990). Progress in Essential Oils. Perfumer \& Flavorist., 15, 45-62

Mellouk, H., Khezami, L., Rezzoug, S.A. and Capart. R. (2008). Total Valorisation of red cedar sawmills wastes by Instantaneous controlled pressure drop process. Isolation of extractives and production of activated carbon from the solid residue. Bioresources, 3 (4), 1156-1172

Nouviaire, A., Louka, N., Rezzoug, S.-A. and Allaf, K. (2001). Séchage-texturation des fraises par le procédé de détente instantanée contrôlée couplé au séchage par convection. Optimisation à l'aide de la méthodologie des plans d'expériences. Sciences des Aliments, $21,177-192$

Mira, B. Blasco, M. and Subirats, S. (1996). Supercritical $\mathrm{CO}_{2}$ extraction of essential oils from orange peel. Journal of Supercritical Fluids, 9, 238-243

Pare, J., Sigomin, M. \& Lapointe, J. (1991). US Patent nº 5.002.784

Pernice, R., Boriello, G., Ferracane, R., Borrelli, R.C. and Cennamo, F. (2009). Bergamot: A source of natural antioxidant for functionalized fruit juices. Food Chemistry, 112, 545-550.

Raeissi, S. and Peters, C.J. (2005). Liquid-vapor and liquid-liquid-vapor equilibria in the ternary system ethane + limonene + linalool. Journal of supercritical fluids, 33, 201-208

Raeissi, S., Diaz, S., Espinosa, S., Peters, C.J. and Brignole, E.A. (2008). Ethane as an alternative solvent for supercritical extraction of orange peel oils. Journal of Supercritical Fluids, 45, 306-313

Redd, J.B. and Hendrix, C.M. In Fruit Juice Processing Technology. S. Nagy, C.S. Chen, P.E. 
Rezzoug, S.A., Louka, N., Maache-Rezzoug, Z., Nouviaire, A. \& Allaf, K. (1998). Présentation du séchage couple a la texturation par détente instantanée contrôlée. Application aux produits agroalimentaires en morceaux. $10^{\text {èmes }}$ Rencontres Scientifiques et Technologiques des Industries Alimentaires. AGORAL. Ed. Lavoisier, Paris. 319-324.

Rezzoug, S. A., Maache-Rezzoug, Z., Mazoyer, J., Jeannin, M. and Allaf, K. (2000). Effect of instantaneous controlled pressure drop process on hydration capacity of scleroglucan. Optimisation of operating conditions by response surface methodology. Carbohydrate polymers, $42,73-84$

Rezzoug, S.A., Baghdadi, M.W., Louka, N., Boutekedjiret, C. and Allaf, K. (1998). Study of a 385 New Extraction Process: Instantaneous Controlled Decompression. Application for Extraction of Essential Oil from Rosemary Leaves. Flavour and Fragrance Journal, 13, 251-258

Rezzoug, S.A., Boutekedjiret, C. \& Allaf, K. (2005). Optimization of operating conditions of rosemary essential oil extraction by a fast controlled pressure drop process using response surface methodology. Journal of Food Engineering, 71, 9-17

Salib, A.G., Saleh M.A., Abdel-Malik, G.S. (1978). Chemical and physical Studies on peel essential oils of some Egyptian citrus fruits. Annals of Agriculture Science, 9, 65-71

Sonsuzer, S., Sahin S. and Yilmaz, L. (2004). Optimization of supercritical $\mathrm{CO}_{2}$ extraction of Thymbra spicata oil, Journal of Supercritical Fluids, 30, 189-199.

Spiro, M., and Chen, S. S. (1994). Kinetics of solvent extraction of essential oil from rosemary leaves. Flavour and Fragrance Journal, 10, 187-200.

Spiro, M., and Selwood, R. M., (1984). The kinetics and mechanism of caffeine infusion from coffee: The effect of particle size. Journal of the Science of Food and Agriculture 35, 915924

397 Statgraphics Plus for Windows 5.1. Experimental Design. Manugistics, Inc. 1994

398 Statgraphics Plus for Windows 5.1. User Manual. Manugistics, Inc. 1994

399 Tateo. F. (1990). Production of Concentrated Orange Oils Using a Thin Film Evaporator. 
401

402

403

404

405

406

407

408

409

410

411

412

413

414

415

416

417

Temelli, F. Chen, C.S. and Braddock, R.J. (1988). Supercritical Fluid Extraction in Citrus Oil Processing. High-pressure $\mathrm{CO}_{2}$ system concentrates aroma and flavor compounds in citrus oils. Food Technogy, 42, 145-150

Viuda-Matros, M., Ruiz-Navajas, Y., Fernández-López, J. and Pérez-Álvarez, J. (2008). Antifungal activity of lemon (Citrus lemon L.), mandarin (Citrus reticulata L.), grapefruit (Citrus paradisi L.) and orange (Citrus sinensis L.) essential oils., Food Control, 19, 1131138.

Wang, L., Yang, B., Du, X., Yang, Y. and Liu, J. (2008). Optimisation of conditions for extraction of acid-soluble collagen from grass carp (Ctenopharyngodon idella) by response surface methodology. Innovative food science and emerging technologies, 9, 604-607.

Wu, Y., Cui, S.W., Tang, J. and Gu, X. (2007). Optimisation of extraction process of crude polysaccharides from boat-fruited sterculia seeds by response surface methodology. Food Chemistry, 105, 1599-1605.

Yu, J., Dandekar, D.V., Toledo, R.T., Singh, R.K. and Patil, B.S. (2007). Supercritical fluid extraction of limonoids and naringin from grapefruits (Citrus paradisi, Macf.) seeds. Food Chemistry, 105, 1026-1031.

Zeboudj, S., Belhanèche-Bensemra, N. and Belabbès, R. (2005). Use of surface response methodology for the optimization of the concentration of the sweet orange essential oil of Algeria by wiped film evaporator. Journal of food engineering, 67, 507-512

Zia-ur-Rehman. (2006). Citrus peel extract - A natural source of antioxidant. Food Chemistry, $99,450-454$ 
428 Fig.1. Schematic of the apparatus used for extraction. 1. Boiler, 2. Pressure vessel, 3.Butterfly valve, 4. Vacuum tank, 5. Water ring vacuum pump, 6. Extract container. All parts and valves of the apparatus are made of stainless steel.

431 Fig.2. Typical pressure-time profile for DIC processing cycle.

$432 \quad$ Fig.3. Characterization procedure of isolated orange peel oil

433 Fig.4. Responses surfaces of the extracted oil yield as a simultaneous function of two operating parameters. For each figure, the third variable is fixed at " 0 " level

435 Fig.5. Kinetics of orange peel oil extracted by steam distillation ( $-\circ)$ ) and by D.I.C extraction process $(\bullet-)$ at 7 bar, $35 \%$ d.m

Fig.6. Extracted oil obtained by: (a) steam distillation (80 min.); (b) D.I.C extraction process (7 bar and $0.35 \mathrm{~g} \mathrm{H}_{2} \mathrm{O} / \mathrm{g}$ of dm, 4 min.)

Fig.7. First-order plots for the two stages of oil isolation orange peel by the thermomechanical process (a) and by steam distillation (b). The semi-empirical factors were obtained as follows: (1): $\mathrm{k}_{1}=0.755 \mathrm{~min}^{-1}$; (2) $\mathrm{k}_{2}=0.095 \min ^{-1}$; (3) $\mathrm{k}_{1}=0.033 \mathrm{~min}^{-1}$; (4) $\mathrm{k}_{2}=0.090 \mathrm{~min}^{-1}$

Fig.8. Contours plots showing the simultaneous effects of processing pressure and initial 443 moisture content at the optimal processing time selected by the developed equation (processing time: $3.68 \mathrm{~min}$.) 
Figure 1.

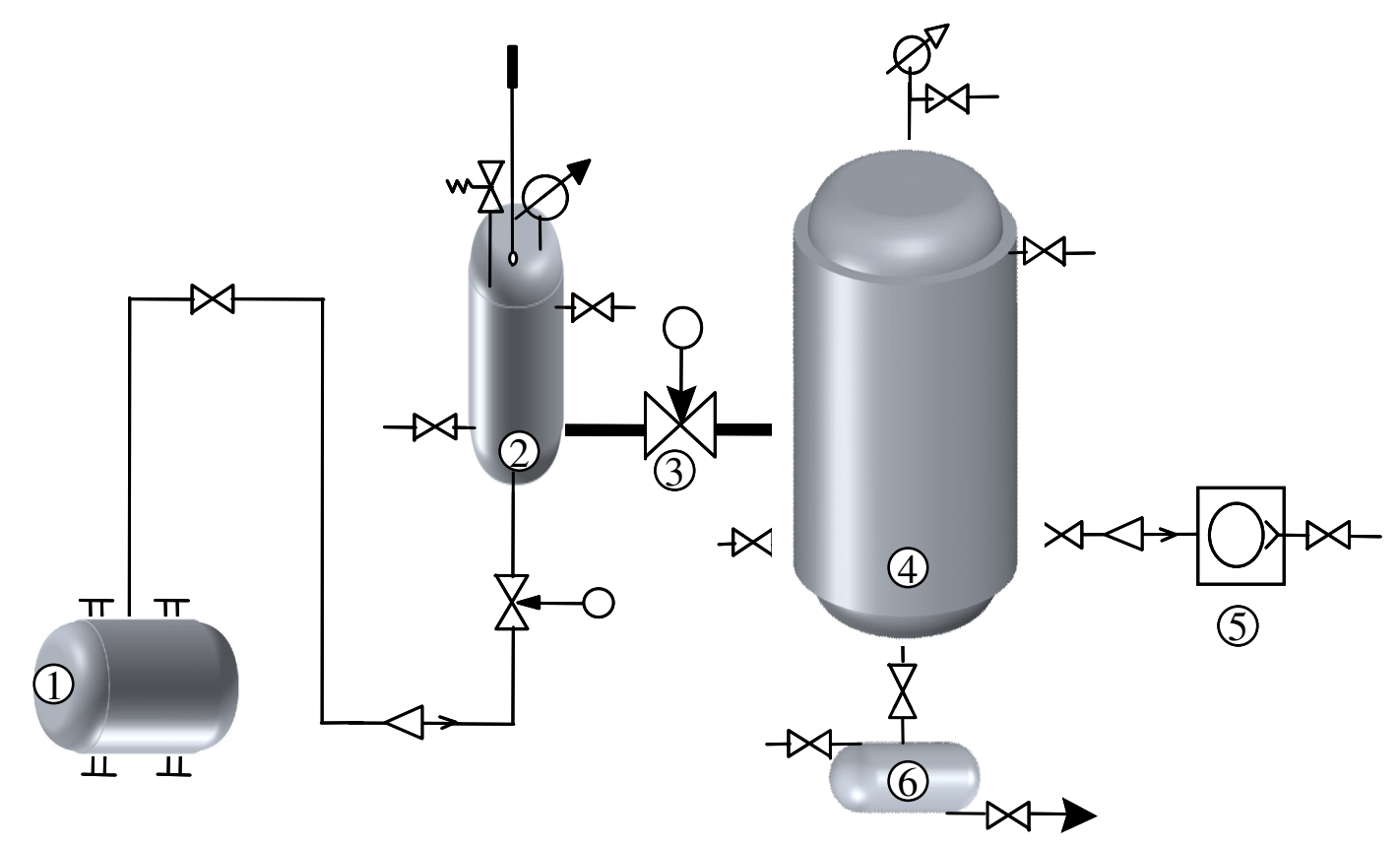


Figure 2

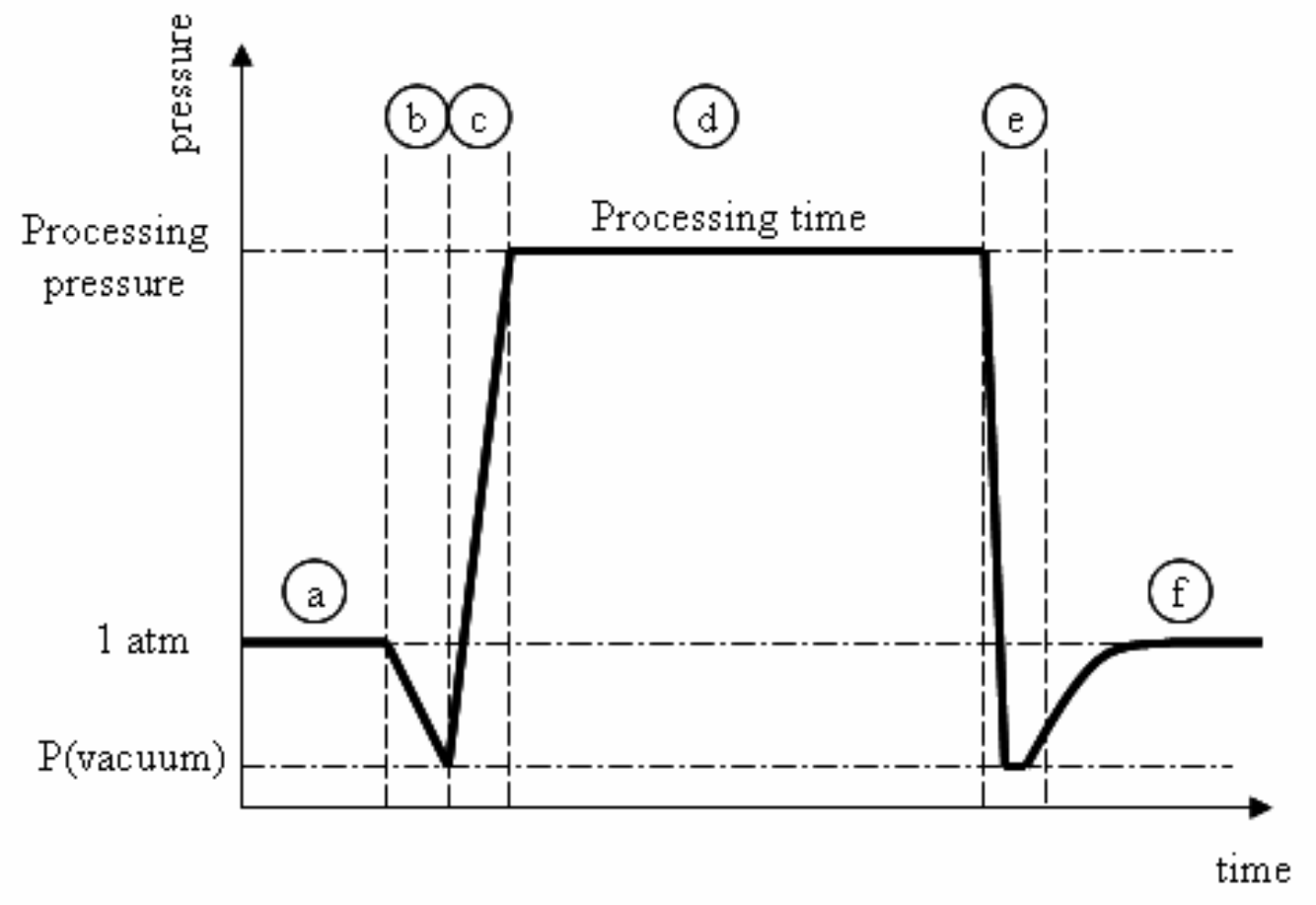


Figure 3.

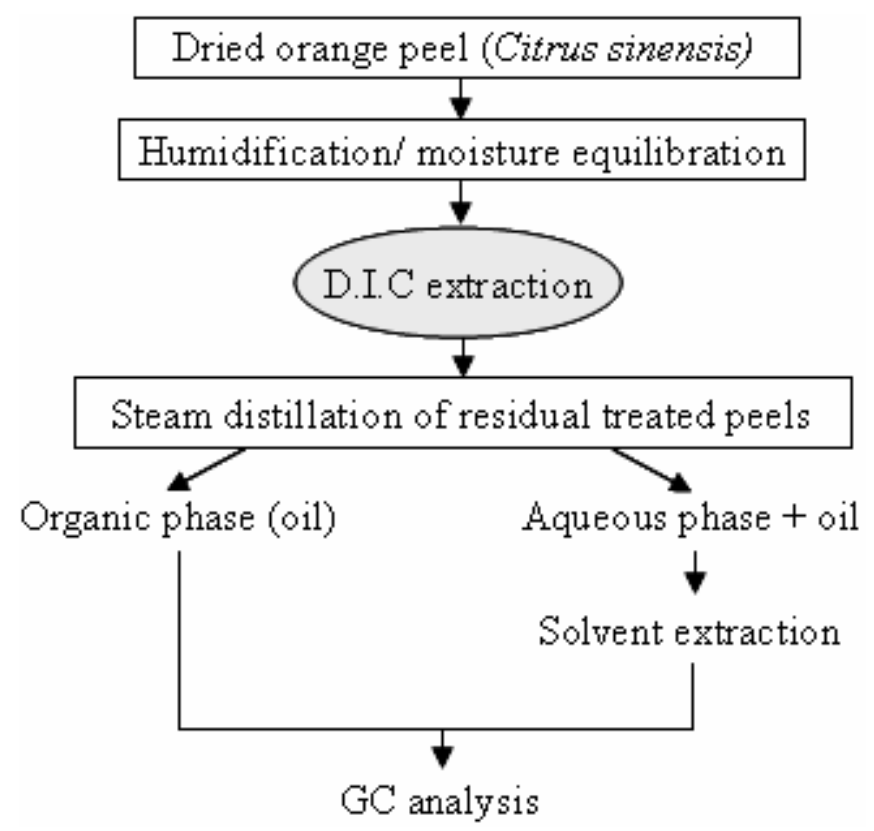



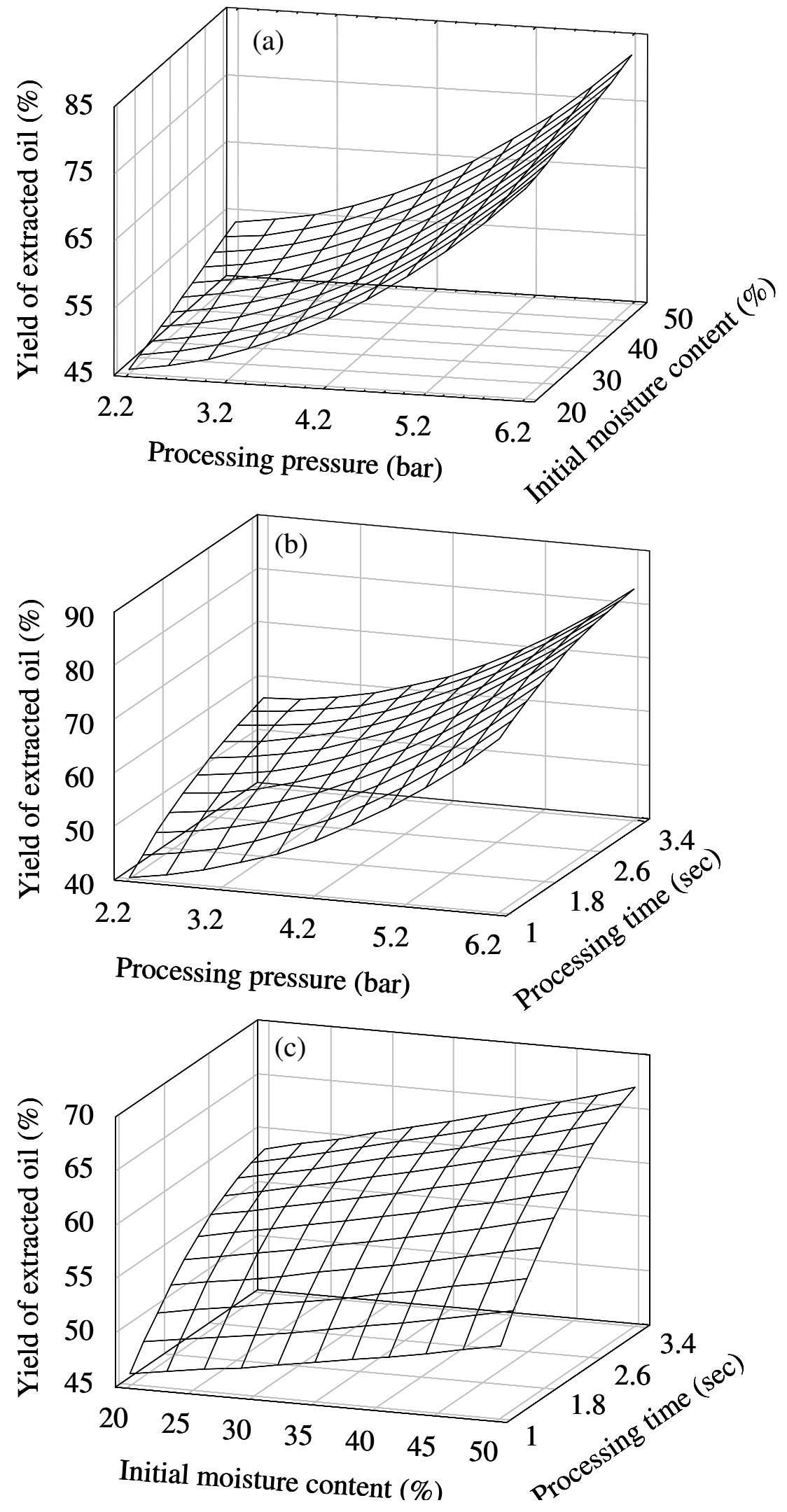
Figure 5

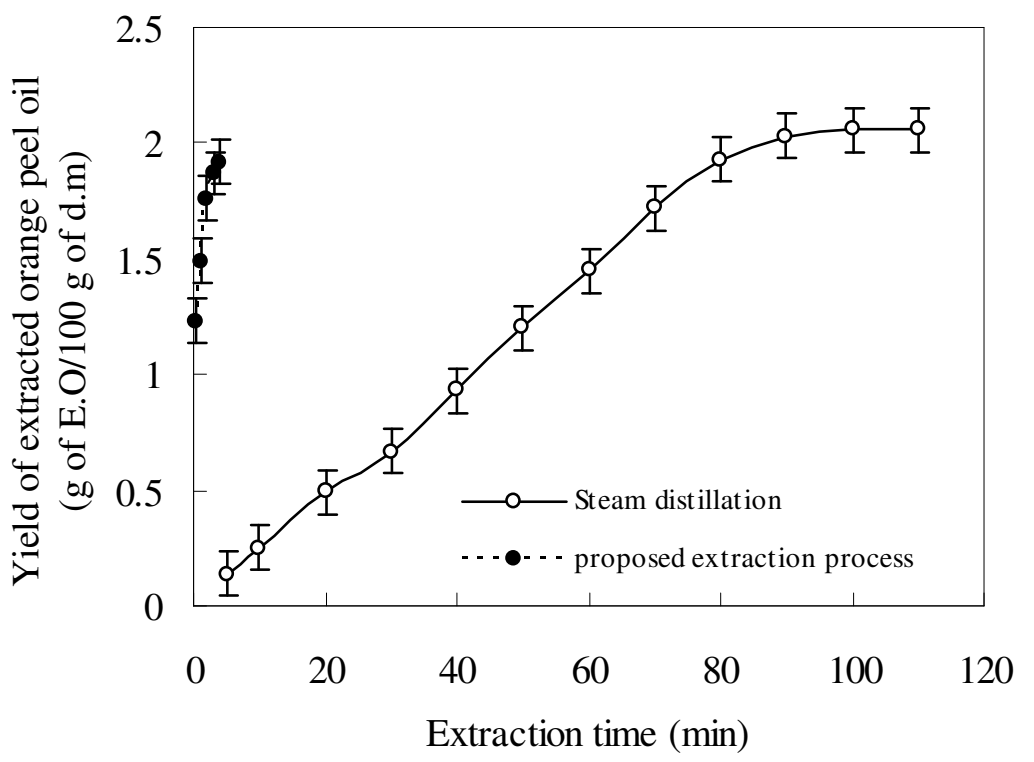


Figure 6

452

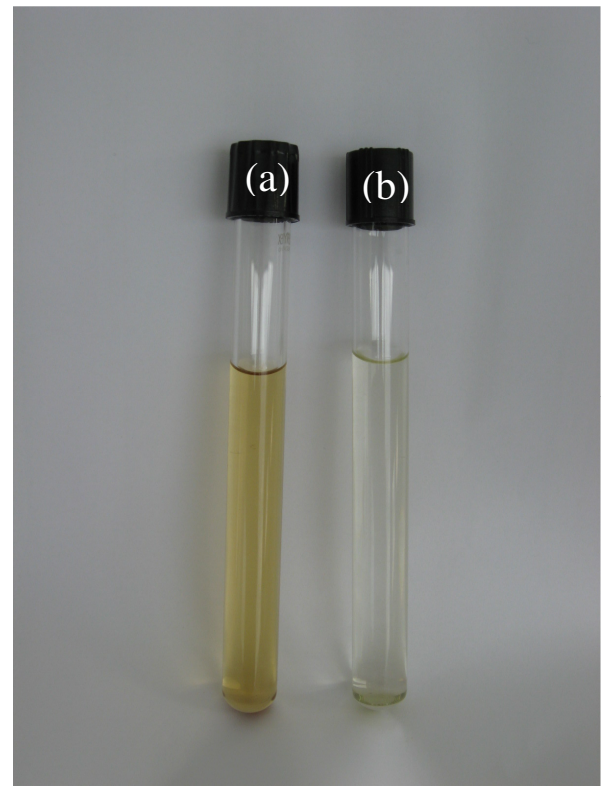


454

455

456

457

458
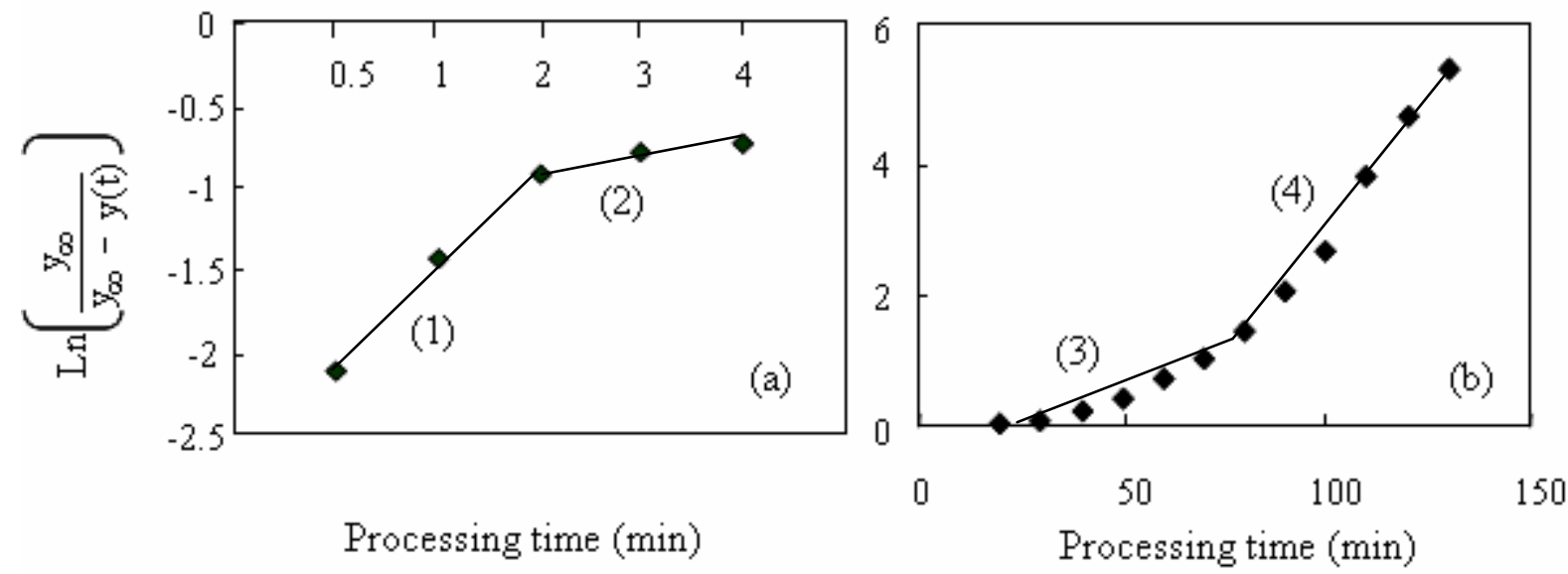

460

\section{Processing time (min)}




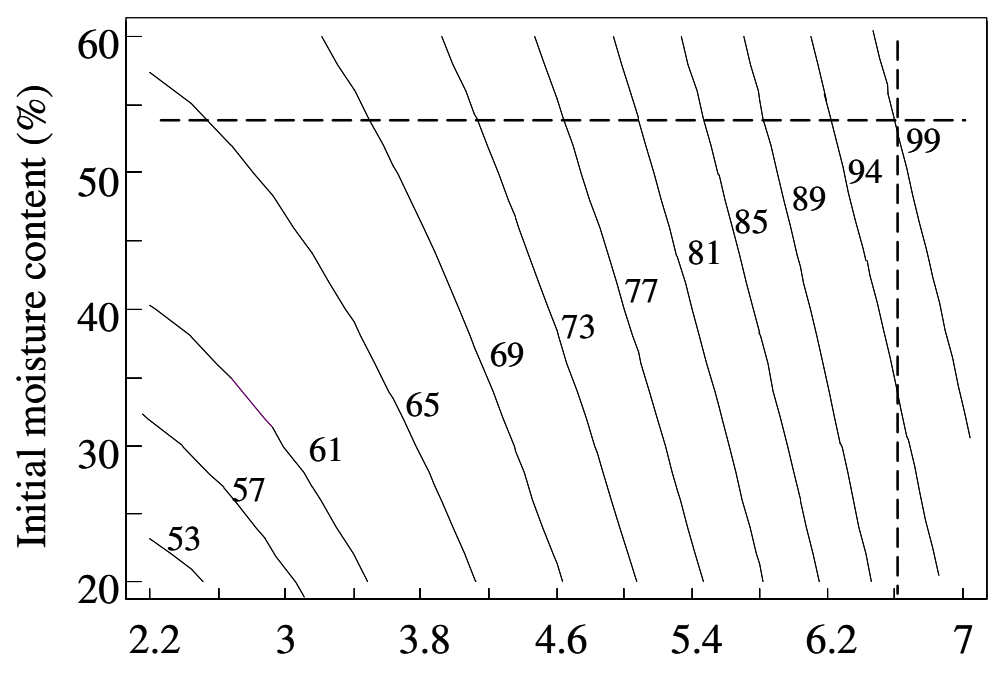

Processing pressure (bar) 
Table 1. Percentage composition of orange peel oil isolated by steam distillation

\begin{tabular}{ccc}
\hline Constituents & $\mathrm{g} / 100 \mathrm{~g}$ of E.O & $\mathrm{Rt}^{*}$ \\
\hline$\alpha$-pinene & 0.5 & 2.87 \\
$\beta$-pinene & 0.38 & 3.76 \\
myrcene & 1.3 & 4.24 \\
limonene & 94.4 & 5.63 \\
linalool & 0.39 & 7.28 \\
\hline
\end{tabular}

* Retention time; E.O: extracted oil 
Table 2. Coded levels for independent variables used in developing experimental

466 data and the temperature corresponding to processing pressure

\begin{tabular}{cccccc}
\hline & \multicolumn{5}{c}{ Coded level } \\
\cline { 2 - 6 } & $-\alpha$ & -1 & 0 & 1 & $+\alpha$ \\
\hline Pressure (bar) & 0.97 & 2.2 & 4 & 5.8 & 7.02 \\
\hline (Corresponding temperature $\left.{ }^{\circ} \mathrm{C}\right)$ & 100 & 123.3 & 143.6 & 158 & 165 \\
\hdashline Moisture content $(\%)$ & 9.8 & 20 & 35 & 50 & 60.2 \\
Processing time (min) & 0.32 & 1 & 2 & 3 & 3.7 \\
\hline
\end{tabular}
factorial design. In this case $\alpha=1.6818$. 
469 Table 3. Experimental data and yield for orange peel essential oil with different 470 combinations of processing pressure $\left(x_{1}\right)$, initial moisture content of peels $\left(x_{2}\right)$ and 471 processing time $\left(x_{3}\right)$ used in the randomized central composite design

\begin{tabular}{cccccccc}
\hline & \multicolumn{2}{l}{ Independent variables } & & \multicolumn{3}{c}{ responses } \\
\cline { 2 - 3 } \cline { 6 - 7 } Run & $x_{1}$ & $x_{2}$ & $x_{3}$ & & Experimental $(\%)$ & Predicted $(\%)$ & Deviation $(\%)$ \\
\hline 1 & 1 & 1 & 1 & & 81.06 & 81.48 & 0.42 \\
2 & 1 & -1 & 1 & & 79.61 & 74.11 & 5.50 \\
3 & 1 & 1 & -1 & & 67.96 & 69.46 & 1.50 \\
4 & 1 & -1 & -1 & & 73.78 & 74.61 & 0.83 \\
5 & -1 & 1 & 1 & & 54.85 & 58.06 & 3.21 \\
6 & -1 & -1 & 1 & & 56.31 & 56.71 & 0.40 \\
7 & -1 & 1 & -1 & & 42.23 & 43.77 & 1.54 \\
8 & -1 & -1 & -1 & & 41.74 & 39.09 & 2.65 \\
9 & $-\alpha$ & 0 & 0 & & 50.00 & 49.92 & 0.08 \\
10 & $+\alpha$ & 0 & 0 & & 85.42 & 88.08 & 2.66 \\
11 & 0 & $-\alpha$ & 0 & & 38.83 & 51.48 & 12.65 \\
12 & 0 & $+\alpha$ & 0 & & 70.38 & 68.30 & 2.08 \\
13 & 0 & 0 & $-\alpha$ & & 36.89 & 41.22 & 4.33 \\
14 & 0 & 0 & $+\alpha$ & & 61.65 & 62.90 & 1.25 \\
15 & 0 & 0 & 0 & & 56.90 & 56.71 & 0.19 \\
16 & 0 & 0 & 0 & & 56.31 & 56.71 & 0.41 \\
17 & 0 & 0 & 0 & & 58.25 & 56.71 & 1.54 \\
18 & 0 & 0 & 0 & & 56.67 & 56.71 & 0.04 \\
19 & 0 & 0 & 0 & 56.65 & 56.71 & 0.06 \\
20 & 0 & 0 & 0 & 55.80 & 56.71 & 0.91 \\
21 & 0 & 0 & 0 & 55.82 & 56.71 & 0.89 \\
22 & 0 & 0 & 0 & 58.25 & 56.71 & 1.54 \\
\hline
\end{tabular}

Mean absolute error for replications $=0.95 \%$ 


\begin{tabular}{cccc}
\hline Regression coefficients of the model & & P-value \\
\cline { 1 - 1 }$\beta_{0}$ & 58.45 & - \\
\hline$\beta_{1}$ & 24.43 & & $<0.0001$ \\
\hline$\beta_{2}$ & 6.98 & 0.0588 \\
\hline$\beta_{3}$ & 12.85 & 0.0024 \\
\hline$\beta_{11}$ & 8.57 & 0.0095 \\
\hline$\beta_{12}$ & -0.85 & 0.8382 \\
\hline$\beta_{13}$ & -2.065 & 0.6365 \\
\hline$\beta_{22}$ & -0.70 & 0.8820 \\
\hline$\beta_{23}$ & 1.33 & 0.7790 \\
\hline$\beta_{33}$ & -4.46 & 0.3179 \\
\hline
\end{tabular}


473 Table 5. Analysis of variance for the fit of experimental data to response surface model

\begin{tabular}{lcccc}
\hline \multicolumn{1}{c}{ Source } & $\begin{array}{c}\text { Degrees } \\
\text { of } \\
\text { freedom }\end{array}$ & $\begin{array}{c}\text { Sum of } \\
\text { square }\end{array}$ & $\begin{array}{c}\text { Mean } \\
\text { square }\end{array}$ & F-ratio \\
\hline Model & 9 & 3146,35 & 349,59 & $6.53^{\mathrm{a}}$ \\
Linear & 3 & 2769,14 & 923.05 & $17.24^{\mathrm{b}}$ \\
Quadratic & 3 & 363,70 & 121.23 & $2.26^{\mathrm{b}}$ \\
Interactions & 3 & 13,51 & 4.50 & 0.084 \\
Residual & 12 & 642.51 & 53.54 & - \\
Lack of fit & 5 & 463.57 & 92.71 & 3.63 \\
Pure error & 7 & 178.94 & 25.56 & - \\
\hline $\mathrm{R}^{2}$ & \multicolumn{5}{c}{0.89} \\
\hline
\end{tabular}

a : p-value $<0.01$, b: p-va 